\title{
The Role of Hard TQM on the Relationship between Soft TQM and FinancialPerformance of Hotels and Travel Agents in Egypt
}

\author{
Ibrahim EIShaer ${ }^{1,3}$ \\ Alaa M. Shaker ${ }^{2,3}$ \\ ${ }^{1}$ School of Business- King Faisal University- KSA; ${ }^{2}$ Faculty of Arts- King Faisal University- KSA, \\ ${ }^{3}$ Faculty of Tourism and Hotels- Suez Canal University- Egypt,
}

\section{Abstract}

In the last 60 years, Total Quality Management (TQM) has been under review (theoretically) and under examination (empirically) from several scholars all over the world. Although TQM practices in the manufacturing industry are well studied, fewer attempts have been conducted to examine its connotations and effects in the service industry, and particularly in the tourism sector. Two main categories of TQM practices were explored: Soft TQM (STQM) activities/practices and Hard TQM (HTQM) activities/practices. It is arguable that both TQM practices enhance financial performance, but these relationships have not been completely tested in the tourism sector. The main aim of this paper is to assess the impact of STQM on financial performance through the mediating role of HTQM practices. The data were collected from surveying 380 general managers working in hotels and travel agents in Egypt. A total of 285 valid questionnaires were attained with a response rate reached $75 \%$. Structural equation modelling (SEM) results indicate that STQM improves financial performance, and HTQM has a direct influence on financial performance. The results show that 14 out of 15 proposed hypotheses were supported. Therefore, it is important that hotels and travel agents allocate their resources to implement both STQM and HTQM practices to exploit the effectiveness and efficiency of the entire TQM system. Finally, general conclusions and limitations are outlined. Keywords: TQM, Soft TQM, Hard TQM, performance, SEM, Egypt.

\section{Introduction}

Quality gurus have stressed the importance of TQM in improving business performance (Juran, 1988; Deming, 1982; and Juran and Godfrey 1999).TQM importance has been proved both in empirical studies (e.g. Flynn et.,1995; Powell, 1995; Agus and Sagir, 2001; Agus, 2011; Valmohammadi and Roshanzamir, 2015; and Shafiq et al., 2019) and in meta-analysis studies (Nair, 2006; Sila and Ebrahimpour, 2002; Martínez-Costa et al., 2009; Prashar, 2018). Despite the existence of a significant body of literature concerning this relationship, little is known of the effect of TQM, defined as "coordinated activities to direct and control an organization with regard to quality" (ISO, 2005:21), upon the organization performance of service firms and, in particular, hotels and travel agents. Additionally, previous empirical studies demonstrate contradictory findings with regard to the impact of STQM practices (e.g. leadership of top management, management of employees, and focus on the customer) and HTQM practices (e.g. data quality \&monitoring, and management of process) upon business performance (Sousa and Voss, 2002). While some studies concluded that the STQM practices can only affect performance through the HTQM practices (e.g. Flynn et al., 1995; Kaynak, 2003; Zu et al., 2008; Zu, 2009), other scholars found that only STQM practices can enhance the performance, but the HTQM cannot (e.g. Samson and Terziovski, 1999; Powell, 1995). There is also empirical evidence to suggest that some STQM practices such as customer focus (Sila and Ebrahimpour, 2005), top management leadership and employees' management (Motwani et al. 1994) cannot significantly improve business performance.

The above inconsistencies might be due to differences in the dimensions that were used to measure both TQM and performance or due to other methodological limitations of previous studies such as sampling limitations or the use of different analytical methods. For example, 
Powell (1995) used 11 factors to measure TQM but it was found that only three STQM dimensions (i.e. executive engagement, open organization, and employee empowerment) were positive and significantly associated with performance, while the other STQM practices (i.e. implementing the quality philosophy, closeness to end-user, closeness to suppliers), and the HTQM practices (flexible production, benchmarking, zero/no defects, process continuous improvement) were not substantially to linked to performance. In different context, Flynn et al. (1995) employed8factors to operationalize TQM, of which four STQM practice (i.e. relationship with customer, relationship with supplier, support from top management, management of workforce) and three HTQM practices (i.e. process of product design, work attitudes, and statistical feedback /evaluation) positively enhance performance; while one HTQM factor (process flow management) was not related to the performance. While the use of different factors to operationalize TQM and performance might be the reason behind the inconsistent results generated from these two studies, the employment of different analytical methods and the context in which these studies were conducted may also explain such contradictory results. Indeed, while Powell (1995) implement the study in 54 manufacturing and service firms located in USA and correlation analysis was the main data analysis technique, Flynn et al. (1995) examined only 42 USA manufacturing firms and used path analysis.

Considering the limitations and inconsistencies of the former studies, the main goal of this research paper is to improve our knowledge and understanding of the interrelationships between STQM and HTQM practices and their potential impacts on the financial performance. The study is carried out in the context of Egyptian hotels and travel agents. In this study, Flynn et al. (1995) classification of TQM to STQM and HTQM practices is adopted with four STQM practices (leadership of top management, management of employees, focus on the customer, and management of suppliers) and two HTQM practices (data quality and reporting and management of process). Financial performance is operationalized by two variables: productivity of employees and per room revenue (for hotels) or revenue per guest (for travel agents). A theoretical framework was established from the analysis of prior research to explain the interrelationships between STQM and HTQM practices and their likely impacts on financial performance. Using survey data from 285 general managers employed in hotels (five and fourstar) and Class A travel agents in Egypt, SEM with Amos v18 is employed to assess the research model.

\section{Theoretical framework and research hypotheses}

Flynn et al. (1995) categorized TQM activities to two main sets: (1) HTQM activities that covers TQM tools and techniques such as product design; management of process, data quality and reporting, and (2) STQM activities which establish a supportive environment for efficient utilization of HTQM practices and covers customer focus (CF), top management leadership (TML), supplier Management (SM), employee management (EM), and quality data and reporting (QD\&R). The relationships between these groups of TQM practices and performance were subsequently studied using a variety of performance scales, including financial performance, product quality, customer satisfaction, and competitive advantage ( $\mathrm{Su}$ et al., 2008; Kumar et a., 2009; Eriksson and Hansson, 2013; Elshaer and Augustyn, 2016; Lamine and Lakhal, 2018,).

For this study, measures of TQM used in the extant empirical studies were analyzed with a view to identifying those soft and HTQM practices that may have an effect on business performance. This process has resulted in identifying six potential dimensions of TQM. Four of them are STQM: CF, TML, SM, and EM, and two are HTQM: QD\&R, and PM. Each dimension has its related indicators. A continuous scale of 0 to 10 was used to calculate how long a TQM technique had been put into practice. 
While business performance is often operationalized by subjective (perceptual) measures (e.g. Lakhal, 2005; Zu, 2009; and Valmohammadi and Roshanzamir, 2015), financial performance is operationalized in this research by two objective variables (productivity of employees and per room revenue), as subjective measures naturally encompass regular (biases) and random errors (Bollen and Paxton 1998; Augustyn et al., 2019).

The literature review confirms the existence of correlations between TQM factors and financial performance, which constitute the basis for formulating the following research hypothesis.

First, several studies have shown that Top Management Leadership (TML) is a significant method in effectively implementing TQM and enhancing business performance (Prajogo and Browln, 2004; Barker and Emery, 2006; and Gözükara et al., 2019). TM demonstrates its commitment to TQM by assuming responsibility for quality leadership through the procurement of resources needed to implement TQM activities (Kaynak and Hartley, 2007; Zu, 2009; Elshaer and Augustyn, 2016) and quality preparation (Marta et al., 2005).TML serves as a catalyst for TQM implementation by developing priorities, strategies, principles, and frameworks to meet the requirements of consumers and other stakeholders to enhance business performance (Sila and Ebrahimpour, 2005; Tari et al., 2007;Augustyn et al., 2019).Several empirical studies in this context found positive effects of TML on other TQM practices such as CF (Kristianto et al., 2013), EM (; Zelnik et al., 2012), SM (Tari et al., 2007), QD\&R (Lakhal et al., 2006; Augustyn et al., 2019), and PM (Flynn et al., 1995; Sila and Ebrahimpour, 2005; Kaynak, 2003; Lakhal et al., 2006; Augustyn et al., 2019). The following hypotheses therefore emerge:

H 1a. TML has a positive impact on CF.

H 1b. TML has a positive impact on EM.

H 1c. TML has a positive impac ton SM.

$H$ ld: TML has a positive impact on financial performance through $Q D \& R$.

$H$ 1e: TML has a positive impact on financial performance through PM.

Second, several studies have demonstrated the importance of employee management to a successful implementation of TQM and improved business performance (e.g. Rahman and Bullock, 2005; Kaynak, 2003; Zelnik et al., 2012andElshaer and Augustyn, 2016).This is because the efficiency of quality systems relies on individuals who can operate upon such processes (Tari et al., 2007), which in turn raises income (Flynn et al., 1995; Lakhal et al., 2006; Kaynak, 2003; Imran et al., 2014; andAugustyn et al., 2019).Often, as workers are qualified to use standard tools and methods (such as cause-effect graphs, Pareto charts), it is possible to improve variation and recognize areas for improvement. Employees can understand issues concerning productivity, enhance work processes, product quality and overall business performance (Deming, 1982; Flynn et al., 1995; Kaynak,2003; and Imran et al., 2014). The following hypotheses emerge from this literature:

$H$ 2a: EM has a positive impact on the $C F$.

$H 2 b$ : EM has a positive impact on financial performance through PM.

$H$ 2c: EM has a positive impact on financial performance through $Q D \& R$.

Third, given that the main objective of quality initiatives is to meet customer requirements, customer focus plays an important role in increasing the profitability of companies (Sila and Ebrahimpour, 2002; and Sun and Kim, 2013; Elshaer and Augustyn, 2016). CF is confirmed by meeting customer requirements in business processes (Ahire et al., 1996) and by gathering customer reviews that permits adjustments to the processes to be made, which progresses the overall business performance (Tari et al., 2007; and Sun and Kim, 2013). Based on the existing evidence, the following hypotheses are proposed:

$H$ 3a: CF has a positive impact on financial performance through PM. 
$H$ 3b: CF has a positive impact on financial performance through $Q D \& R$.

Fourthly, there is evidence to suggest that collaboration and integration with suppliers has a positive impact on business performance (Rahman and Bullock, 2005; and Lakhal et al., 2006; $\mathrm{Yu}$ et al., 2013; Elshaer and Augustyn, 2016). The production of quality products depends essentially not only on the quality of the data collected about that product but also on the quality of the supplied materials and components (Flynn et al., 1995). Therefore, through enhancing the quality of the obtained materials and tools with effective supplier management, the variability in materials and components can be minimized, which could lead to a reduction in reprocessing and waste and thus increase the profitability of the business (Flynn et al., 1995; Tari et al., 2007; Elshaer and Augustyn, 2016). The following hypotheses therefore emerge:

H4a: SM has a positive impact on financial performance through PM.

$H 4 b$ : SM has a positive impact on financial performance through $Q D \& R$.

Fifth, current empirical studies indicate that quality data and reporting are an important practice of TQM in improving business performance (Kaynak, 2003; Sila and Ebrahimpour, 2003; Lakhal et al., 2006; and Nair, 2006; Augustyn et al., 2019). This is because assessment and decisionmaking at all levels of the company must be assisted by significant information processes to enhance quality and total business performance (Sila, and Ebrahimpour, 2005). Therefore, the examination of information quality supports companies in attaining the favorite quality standards and improve their productivity (Rao et al., 1999; Sila, and Ebrahimpour, 2005; Augustyn et al., 2019). Many studies (e.g. Sila, and Ebrahimpour, 2005; Lakhal et al., 2006; Elshaer and Augustyn, 2016) have found a direct positive link between quality data and reporting and business performance. Quality data affects management of process by immediately informing employees about process changes so they can take corrective action before manufacturing defective items, which improves business results (Sila, and Ebrahimpour, 2005). The following hypotheses therefore emerge:

$H$ 5a: $Q D \& R$ have a positive impact on financial performance.

$H$ 5b: QD\&R have a positive impact on PM.

Sixthly, there is evidence that process management, which aims to improve production techniques and processes by creating error-proof processes to eliminate process deviations (Flynn et al., 1995; Saraph et al., 1989), improves productivity and profitability by using preventive action to improve reliability and eliminate production interruptions(Kaynak, 2003; Sila, and Ebrahimpour, 2005; Elshaer and Augustyn, 2016). Accordingly, the following hypothesis emerges:

Hypothesis 6a: PM has a positive impact on financial performance.

\section{Research methodology \\ Data collection}

In this research, data were gathered from surveying 384 General Managers working in Egyptian hotels and travel agents to assess the impact of STQM and HTQM practices on financial performance. A sum of 300 responses was attained (140 from 5- and 4-star hotels, and 160 from Class A travel agents). Fifteen uncompleted questionnaires have been deleted, leaving 285

questionnaires with a response rate of $75 \%$. General Managers completed all of the questionnaires.

\section{Tests for Reliability and Validity.}

For the six TQM dimensions, the composite Cronbach Alpha values scores represent an acceptable internal consistency for all elements. The reliability scores of all CF,TML, SM,EM, QD\&R, and PM average scales (Cronbach Alpha or $\alpha$ ) surpass 0.91 (see Table 1), which exceeds the normal cut-off point of 0.7 as Nunnally and Bernstein (1994) advise. A construction's internal 
reliabilities (Cronbach's alpha) ranged from 0.83 to 0.95 , both exceeding the lowestvalue of 0.60 (Bagozzi and Yi, 1988). In addition, the Corrected item-total Correlation (CITC) has been used as a common measure of internal consistency within the items of variables that represent the level of correlation among each item and the entire score. CITC was employed to assess whether all tests had a dominant load on the hypothesized factor and had no noticeable cross-loads. CITC outcomes varied from 0.82 to 0.95 . Such findings are satisfactory and are above the 0.4 value, as Nunnally and Bernstein (1994) suggested.

The measurement model was evaluated in relation to the two forms of construct validity prior to evaluating the structural model: convergent and discriminant validity. Discriminant validity seeks to show that a measure does not overlap with other measures which do not include theoretical relationships (Hair et al., 2009-2017). While, Convergent validity, is about determining the level of a positive relationship between scale items established to measure the same notions (Nachmias and Nachmias, 2007; Hair et al., 2017). The statistical significance of the loadings (e.g. t > 1.96) indicates converging validity. If the factor loading of an item is greater than 0.7 , it means that the latent variable will explain nearly half of the variance of the item. Thus, 0.7 is the threshold for the factor loading to a construct or dimension of the item (Fornell and Larcker, 1981).The measurement section in Figure (1) shows that loadings of all factors are significant and exceed 0.7 , confirming an accepted convergent validity of the scales. In addition, evidence of discriminant validity may be provided if the composite alpha coefficients of the factors exceed their correlation coefficients (Eisingerich and Bell, 2007). Table (1) shows that the alpha composite coefficients for CF, EM,TML, SM, QD\&R, and PM extended from 0.91 to 0.96 and surpassed their correlation scores $(0.50$ to 0.74$)$ and other correlations with any other constructs which give evidence that discriminant validity is achieved.

\begin{tabular}{|c|c|c|c|c|c|c|c|}
\hline construct & $\alpha$ & (TML) & (EM) & (SM) & (CF) & (QD\&R) & (PM) \\
\hline TML & .94 & 1 & $0.69 * * *$ & $0.57 * * *$ & $0.70 * * *$ & $0.65 * * *$ & $0.71 * * *$ \\
\hline EM & .95 & $0.69 * * *$ & 1 & $0.39 * * *$ & $0.62 * * *$ & $0.58 * * *$ & $0.59 * * *$ \\
\hline SM & .96 & $0.57^{* * *}$ & $0.39 * * *$ & 1 & $0.39 * * *$ & $0.62 * * *$ & $0.72 * * *$ \\
\hline CF & .91 & $0.70 * * *$ & $0.62 * * *$ & $0.39 * * *$ & 1 & $0.59 \div * *$ & $0.58 * * *$ \\
\hline QD\&R & .95 & $0.65 * * *$ & $0.58 * * *$ & $0.62 * * *$ & $0.59 * * *$ & 1 & $0.68 * * *$ \\
\hline PM & .95 & $0.71 * * *$ & $0.59 * * *$ & $0.72 * * *$ & $0.58 * * *$ & $0.68^{* * *}$ & 1 \\
\hline
\end{tabular}

*** Correlation is significant at the 0.00 level (2-tailed), $\alpha=$ Composite Cronbach Alpha.

* TML=total management leadership; EM =employee management; CF= customer focus; SM= supplier management; * TML=total management leadership; $E M=e m p l o y e e ~ m a n a g e m$
QD\&R= quality data and reporting; PM= process management

\section{Results of the structural model}

Several tests were conducted to determine the structural model goodness of model fit (GOF), such as absolute fit measurements: $\pi 2 / \mathrm{df}$, SRMR, and RMSEA; incremental fit measurements: such as CFI, NFI, and TLI; and Parsimony fit measurement: such as PCFIand PNFI (Hair et al., 2009; Byrne, 2010). Table (2) presents information about fit indices from the data employed in the structural model assessment. Table (2) also shows that the model fits well into the results.

Table 2: Summery of model fit indices for the proposed model

\begin{tabular}{|c|c|c|c|c|c|c|c|c|}
\hline \multirow{6}{*}{$\begin{array}{l}\text { Research } \\
\text { model }\end{array}$} & \multicolumn{8}{|c|}{ Obtained fit indices } \\
\hline & \multicolumn{3}{|l|}{ AFM } & \multicolumn{3}{|l|}{ IFM } & \multicolumn{2}{|l|}{ PFM } \\
\hline & CMIN/df & RMSEA & SRMR & CFI & NFI & TLI & PNFI & PCFI \\
\hline & 1.65 & 0.08 & 0.048 & 0.89 & 0.95 & 0.97 & 0.84 & 0.81 \\
\hline & Suggeste & fit indices & & & & & & \\
\hline & $\leq 3$ & $\leq 0.08$ & $\leq 0.05$ & $\geq 0.90$ & $\geq 0.90$ & $\geq 0.90$ & $>0.05$ & $>0.5$ \\
\hline
\end{tabular}


Suggestion for indices were adapted from literature: (Byrne, 2010; Hair et al. 2009; Raykov and Marcoulides, 2006; Tabachnic and Fidell, 2007)

Research hypotheses have been checked after having a sufficient model fit. Each path between the latent variables within the structural model represents a specific hypothesis (see Figure 1). There are fifteen hypotheses, reflecting the anticipated relationships betweenthe research variables. Using AMOS v18, SEM was used to evaluate the null hypothesis as shown in Figure (1).

Figure (1): Results of testing the measurement and structure model

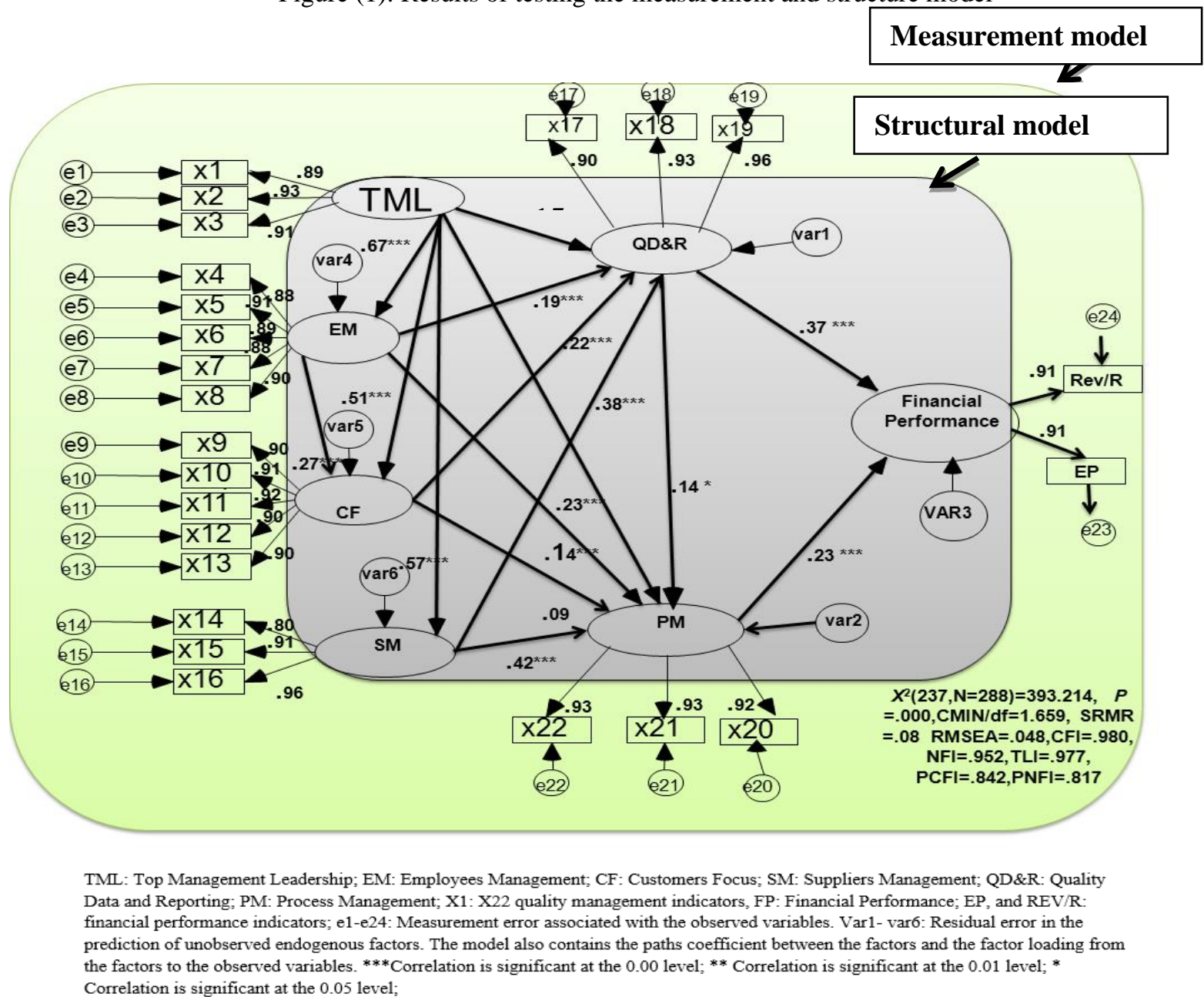

Table (3) illustrates the research hypotheses, standardized regression weights, standard error, tvalue (critical ratio), and the p-significant value. According to Table (3), all the hypothesized relationships were positive and significantly different from zero except the impact of CF on PM. These significant relationships confirm the positive relationships between the research hypotheses.

As discussed below, there are indirect effects of TQM activities on FP as well as the direct relationships shown in Table 3. Through EM, CF, SM, QD\&R, and PM, there are indirect effects of TML on financial performance (Standardized indirect effect=.40). Additionally, through $\mathrm{CF}$ QD\&R and PM, there are indirect effects of EM on financial performance (Standardized indirect effect=.14). Furthermore, through PM and QD\&R there are indirect effects of CF on the financial performance (Standardized indirect effect $=.11$ ). Additionally, through PM and QD\&R there are indirect impacts of SM on financial performance (Standardized indirect effect $=.25$ ). Finally, SEM findings calculate the predictive power of $\left(\mathrm{R}^{2}\right)$ for the endogenous latent variables as 
follows: EM (0.47), CF (0.52), SM (0.32), PM (0.69), QD\&R (0.57), and financial performance (0.31).

Table 3. Hypothesized relationships, Standardized Regression Weights, t-value and p- significant values.

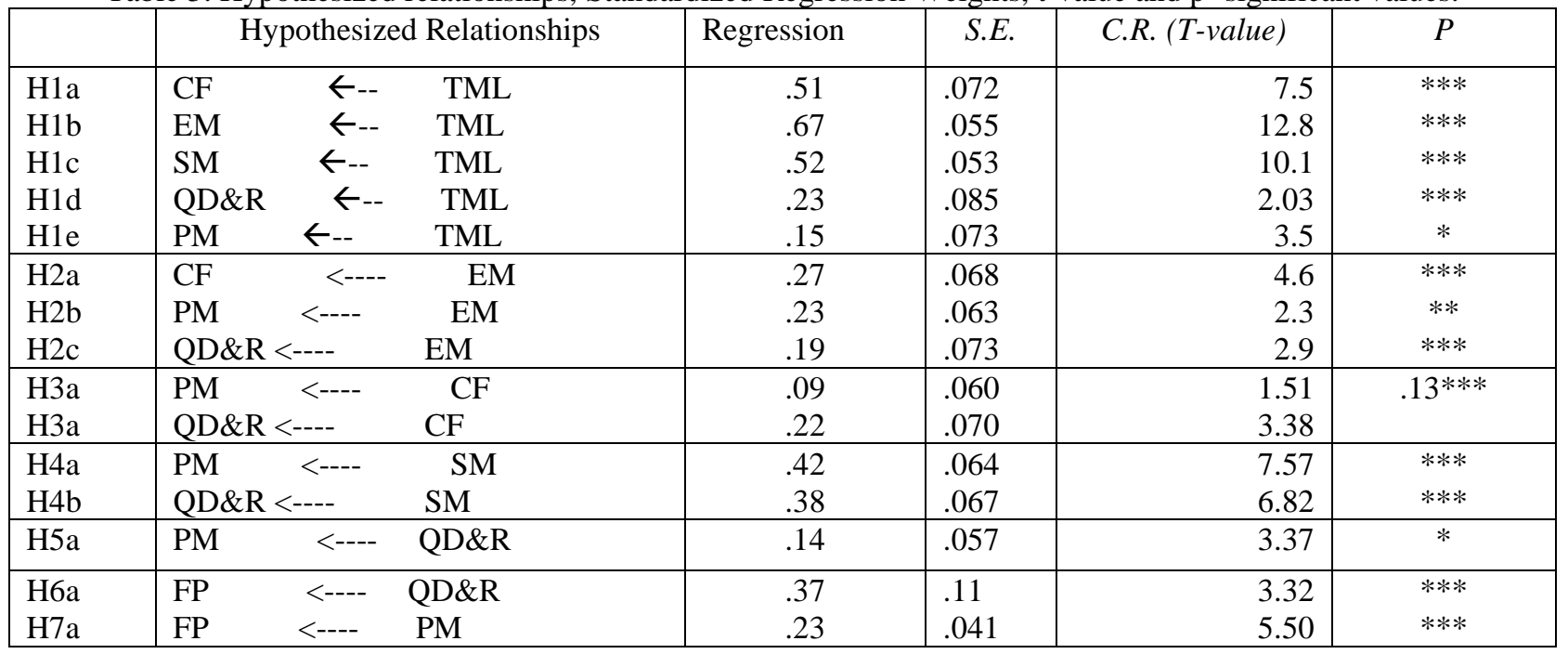

$* * *$ Correlation is significant at the 0.00 level; ** Correlation is significant at the 0.01 level; * Correlation is significant at the 0.05 level; TML: Top Management Leadership; EM: Employees Management; CF: Customers Focus; SM: Suppliers Management; QD\&R: Quality Data and Reporting; PM: Process Management; S.E.: standard error; C.R.: critical ratio.

\section{Discussion}

SEM results show positive regression weights (r) and significant $\mathrm{p}$ value for the impact of TML on all other factors as follows: CF ( $\mathrm{r}=0.51, \mathrm{P}<.001)$; EM ( $\mathrm{r}=0.97, \mathrm{P}<.001)$; $\mathrm{SM}(\mathrm{r}=0.52$, $\mathrm{P}<.001)$; $\mathrm{QD} \& \mathrm{R}(\mathrm{r}=0.23, \mathrm{P}<.001)$; and $\mathrm{PM}(\mathrm{r}=0.15, \mathrm{P}<.05)$ respectively. This confirms that TML is a main driver to implement all other TQM practices by creating goals, policies, values, and systems to meet the requirements of customers and other stakeholders and thus improve business performance.

The positive impact of EM on $\mathrm{CF}(\mathrm{r}=0.27, \mathrm{P}<.001)$ confirms that the management of employees leads to customer orientation. In addition, the direct positive impact on financial performance of both HTQM practices, namely: QD\&R $(r=0.37, \mathrm{P}<.001)$ and $\mathrm{PM}(\mathrm{r}=0.23, \mathrm{P}<.001)$ confirms that organizations (hotels and travel agents) are sets of interlinked processes and that these processes are continuously improved as suggested by Deming (1986). These findings further suggest that not only the availability of quality data but also the review of key information from this quality data will boost the quality performance and the overall financial output as shown by Sila and Ebrahimpour (2005); Elshaer and Augustyn (2016).

Furthermore, the findings of this study show strong evidence of the need for HTQM activities to mediate the effect of STQM practice on tourism industry financial performance, particularly in hotels and travel agents. In the structural model, it is found that the HTQM component directly affects financial performance (as described above), and completely mediates the impact of STQM on financial performance. Such findings are consistent with previous studies, such as those performed by Flynn et al. (1995), Kaynak (2003), Rahman and Bullock (2005), Zu (2009) andAugustyn et al., 2019. The results also support the interdependence theory of QM practices where TQM should be implemented as an integrated strategy (in hotels and travel agents) and where companies need to effectively implement all of the practices to boost their financial performance (Flynn et al., 1995; Yeung et al., 2005; Elshaer and Augustyn, 2016).Finally, the financial performance R2 value (.31) is a high predictive power, taking into consideration the 
substantial inexplicable variance in financial performance, which could be possibly explained by a multitude other factors like new technology, big size, business organization culture and structure, or luck (Samson and Terziovski, 1999).

\section{Conclusions}

This paper contributes to the literature on TQM by presenting clear empirical evidence of the roles of STQM practices (e.g. TML, CF, EM, and SM) and HTQM practices (e.g. PM, and QD\&R) in improving the financial performance of hotels and travel agents. SEM results confirm the direct and indirect effects of HTQM and STQM on financial performance, thereby helping to further explain the conflicting findings of previous studies on those two types of TQM practices. The findings of this study also have important implications for the managers of hotels and travel agents, as this study confirms that the practices of HTQM are essential in improving financial performance and that the practices of STQM support hard practice implementation. Managers should, therefore, devote the resources necessary to implement all types of TQM practices in order to achieve the productivity of the overall TQM program and boost financial performance.

\section{Limitations and further research}

Within the limitations of the study, the results of this study must be interpreted. Firstly, other factors apart from TQM can also enhance the financial performance of the firm. Other considerations include effective marketing campaigns and processes for delivery (Jocumsen, 2002), credibility (Flatt and Kowalczyk, 2008), and strategic alliances (Culpan, 2008).Nonetheless, despite the assumption of Ceteris Paribus introduced in this analysis, all other factors are held constant so that the influence of one single independent variable (TQM) on the dependent variable (financial performance) can be isolated from the effects of other variables.

Second, other models should be tested to affirm or refute the mediating role of HTQM activities in the impact of STQM on financial performance, where the current study model should be contrasted with two other models: (1) partial mediation role of HTQM and (2) no mediation role of HTQM in the effect of STQM on financial performance.

\section{References}

Agus A, Krishnan SK.; and Kadir SLSA (2000). The structural impact of total quality management on financial performance relative to competitors through customer satisfaction: A study of Malaysian manufacturing companies. Total Qual. Manage., 11(4-6), 808-819.

Agus, A. (2011). Enhancing production performance and customer performance through total quality management (TQM): strategies for competitive advantage. Procedia-Social and Behavioral Sciences, 24, 1650-1662.

Agus, A.; and Sagir, R.M. (2001). The structural relationships between total quality management, competitive advantage and bottom-line financial performance: an empirical study of Malaysian manufacturing companies. Total Quality Management, 12(1), 1018-1024.

Ahire, S.L.; and O'shaughnessy, K.C. (1998). The role of top management commitment in quality management: an empirical analysis of the auto parts industry. International Journal of Quality Science 3 (1),5-37.

Ahire, S.L.; Golhar, D. Y. and Waller, M. A. (1996). Development and validation of TQM implementation constructs. Decision Sciences, 27, 23-56.

Augustyn, M. M., Elshaer, I. A., \& Akamavi, R. K. (2019). Competing models of quality management and financial performance improvement. The Service Industries Journal, 39(1), $1-29$. 
Bagozzi, R. and Baumgartner, H. (1994). The evaluation of structural equation models and hypothesis testing. In: Principles of Marketing Research. Blackwell Itd, Brasil, 1(10), 386419.

Barker K. J. and Emery C. R. (2006). The Effect of TQM factors on financial and strategic performance: An empirical test using manufacturing firms. Academy of Strategic Management Journal, 5(1), 39-59.

Bollen, K.A. and Paxton P. (1998). Detection and determinants of bias in subjective measures. American Sociological Review, 63(3), 465-478.

Bullock H.E.; Harlow L.L. and Mulaik S.A. (1994), Causation issues in structural equation modeling research, Structural Equation Modelling, 1 (3), 253-67.

Byrne, B. (2010). Structural Equation Modeling: Basic Concepts, Applications, and Programming. $3^{\text {rd }}$ edition. Mahwah, N.J.; London: Lawrence Erlbaum Associates.

Conca, F.J.; Lopis, J. and Tari, J.J. 2004. Development of a measure to assess quality management in certified firms. European Journal of Operational Research, 156(3), 683697.

Culpan, R. (2008). The Role of Strategic Alliances in Gaining Sustainable Competitive Advantage for Firms. Management Revue, The International Journal of Management Studies, 19 (1\&2), 94-105.

Gözükara, İ., Çolakoğlu, N., \& Şimşek, Ö. F. (2019). Development culture and TQM in Turkish healthcare: the importance of employee empowerment and top management leadership. Total Quality Management \& Business Excellence, 30(11-12), 1302-1318.

De Cerio Merino-Diaz, J. (2003). Quality management practices and operational performance: Empirical evidence for the Spanish industry. Int. J. Prod. Res., 41(12), 2763-2786.

Deming, W.E., (1982). Quality, Productivity, and Competitive Position. MIT Center for Advanced Engineering, Cambridge, MA.

Douglas, T. and Judge, J. W. (2001). Total quality management implementation and competitive advantage: the role of structural control and exploration. Academy of Management Journal, 44(1), 158-169.

Dow, D.; Samson, D. and Ford, S. (1999). Exploding the myth: do all quality management practices contribute to superior quality performance? Production and Operations Management, 8(1), 1-27.

Easton, G.S. and Jarrell, S.L. (1998). The effects of total quality management on corporate performance, an empirical investigation. Journal of Business, 71(1), 253-307.

Eisingerich, A. and Bell, S. (2007). Maintaining customer relationships in high credence services. Journal of Services Marketing,21(4), 253-262.

Elshaer, I. A., \& Augustyn, M. M. (2016). Direct effects of quality management on competitive advantage. International Journal of Quality \& Reliability Management, 33(9), 286-1310

Eriksson, H., \& Hansson, J. (2003). The impact of TQM on financial performance. Measuring Business Excellence, 7(1), 36-50.

Flatt, S. and Kowalczyk, S. (2008). Creating competitive advantage through intangible assets: The direct and indirect effects of corporate culture and reputation. Advances in Competitiveness Research, 16(1),13-30.

Flynn, B. B.; Schroeder, R. G .and Sakakibara, S. (1995). The impact of quality management practices on performance and competitive advantage. Decision Sciences, 26(1), 659-691

Fornell, C. and Larcker, D. (1981). Evaluating structural equation models with unobservable variables and measurement error. Journal of Marketing Research, 18 (1), 39-50. 
Gerbing, D. W. and Anderson, J. C. (1988). An updated paradigm for scale development incorporating unidimensionality and its assessment. Journal of Marketing Research, 25(2), 186-192.

Hair, J., Black, B.; Babin, B.; Ralph, A. and Ronald, T. (2009) Multivariate Data Analysis, $7^{\text {th }}$ edition, London: Prentice-Hall.

Hair Jr, J. F., Matthews, L. M., Matthews, R. L., \& Sarstedt, M. (2017). PLS-SEM or CB-SEM: updated guidelines on which method to use. International Journal of Multivariate Data Analysis, 1(2), 107-123

Ho, D.C.K.; Duffy, V.G.; and Shih, H.M., (1999). An empirical analysis of effective TQM implementation in the Hong Kong electronics manufacturing industry. Human Factors and Ergonomics in Manufacturing, 9(1), 1-25.

Imran, H.;Arif, I.; Cheema, S. and Azeem, M. (2014). Relationship between job satisfaction, job performance, attitude towards work, and organizational commitment. Entrepreneurship and innovation management journal, 2(2),135-144.

ISO 9000. (2005). Quality management systems - Fundamentals and vocabulary. International Organization for Standardization, Geneva, 2000, p. 64.

Jocumsen, G. (2002). Marketing Strategies for Competitive Advantage", European Journal of Marketing, 36(1/2), $273-275$

Juran, J. M., and Godfrey. A.B. (1999). Quality Control Handbook. New York: McGraw-Hill.

Juran, J.M. (1988). On Planning for Quality. New York: Collier Macmillan.

Kaynak, H. (2003). The relationship between total quality management practices and their effects on business performance. Journal of Operations Management, 34(2), 1-31.

Kaynak, H. and Hartley, J.L. (2005). Exploring quality management practices and high tech business performance.Journal of High Technology Management Research, 16 (1), 255-272

Kristianto, Y.; Ajmal, M.M. and Sandhu, M. (2012). Adopting a TQM approach to achieve customer satisfaction: A flour milling company case study. The TQM Journal, 24(1), 29-46.

Kumar, V., Choisne, F.; de Grosbois, D. and Kumar, U. (2009). Impact of TQM on the company's performance. International journal of quality \& reliability management, 26(1), 23-37.

Lakhal. L.(2006). Impact of quality on competitive advantage and organizational performance. The Journal of the Operational Research Society, 60(5), 637-645.

Lambert, L. (1998). Building leadership capacity in schools (Alexandria, VA, USA, Association for Supervision and Curriculum Development.

Lamine, K., \&Lakhal, L. (2018). Impact of TQM/Six Sigma practices on a company's performance: Tunisian context. International Journal of Quality \& Reliability Management, 35(9), 1881-1906.

Lee S. and Kim. W.G. (2009). EVA, refined EVA, MVA, or traditional performance measures for the hospitality industry? International Journal of Hospitality Management, 28(1), 439445

Marta, S.; Leritz, L.E. and Mumford, M.D. (2005). Leadership skills and the group performance: situational demands, behavioral requirements, and planning, The Leadership Quarterly,16 (16), 97-120.

Martínez-Costa, M.; Choi, T.Y.; Martínez, J.A. and Martínez-Lorente, A.R., (2009). ISO 9000/1994, ISO 9001/2000 and TQM: The performance debate revisited. Journal of Operations Management, 27(6), 495-511. 
Motwani, J.G.; Mahmoud, E. and Rice, G. (1994). Quality practices of Indian organizations: An Empirical Analysis", International Journal of Quality \& Reliability Management, 11(1), 3852.

Nachmias, C.F. and Nachmias D. (2007). Research Methods in the Social Sciences Study Guide. Worth Publishers, New York.

Nair, A. (2006). A meta-analysis of the relationship between quality management practices and business performance-implications for quality management theory development. Journal of Operations Management, 24(6), 948-975.

Naveh, E. and Marcus, A. (2005). Achieving Competitive Advantage Through Implementing a Replicable Management Standard: Installing and Using ISO 9000. Journal of Operations Management, 24(1), 1-26.

Nunnally, J. C. (1978) Psychometric theory, 2nd ed. New York: McGraw-Hill.

Powell, T.C. (1995). Total quality management as a competitive advantage: a review and empirical study. Strategic Management Journal, 16(1),15-37.

Prajogo, D.I. and Sohal, A.S. (2006). The relationship between organization strategies, total quality management (TQM), and business performance - the mediating role of TQM. European Journal of Operational Research, 168(1), 35-50.

Prajogo D. I and Brown. A. (2004). The Relationship Between TQM Practices and Quality Performance and the Role of Formal TQM Programs: An Australian Empirical Study. The Quality Management Journal, 11(1), 31-42.

Prashar, A. (2018). TQM as a business strategy: a meta-analysis review. International Journal of Productivity and Quality Management, 23(1), 74-89.

Rahman, S. and Bullock, P. (2005). Soft TQM, hard TQM, and organizational performance relationships: an empirical investigation. Omega, 33(1), 73-83.

Rahman, S. (2001). A comparative study of TQM practice and business performance of SMEs with and without ISO 9000 certification. International Journal of Quality \& Reliability Management, 18(1), 35-49.

Rakov, T. and Marcoulides, G.A. (2006), A first course in structural equation modeling, $2^{\text {nd }}$ Edition, London.

Rao, S.S.; Solis, L.E.; and Raghunathan, T.S., (1999). A framework for international quality management research: Development and validation of a measurement instrument. Total Quality Management, 10(7),1047-1075.

Samson, D. and Terziovski, M. (1999). The relationship between total quality management practices and operational performance. Journal of Operations Management, 17(4), 393-409.

Saraph, J.V.; Benson, P.G. and Schroeder, R.G. (1989). An instrument for measuring the critical factors of quality management. Decision Sciences, 20(4), 810-829.

Saraph, J. V. and R. J. Sebastian. (1993). Developing a quality culture. Quality Progress, 26(9), 73-78.

Sila, I. and Ebrahimpour, M. (2002). An investigation of the total quality management surveybased research published between 1989 and 2000: a literature review. The International Journal of Quality \& Reliability Management; 19, (6/7), 902-970.

Shafiq, M., Lasrado, F., \& Hafeez, K. (2019). The effect of TQM on organizational performance: empirical evidence from the textile sector of a developing country using SEM. Total Quality Management \& Business Excellence, 30(1-2), 31-52.

Sila, I. and Ebrahimpour, M. (2005). Critical linkages among TQM factors and business performance. International Journal of Operations and Production Management 24(11), 1123-1155. 
Sousa, R and., Voss, C. (2002). Quality management re-visited a reflective review and agenda for future research. Journal of Operations Management, 20(1), 91-109.

Su, Q. ; Li, Z., Zhang, Liu, Y.Y. and Dang, J. (2008). The impacts of quality management practices on business performance: An empirical investigation from China. The International Journal of Quality \& Reliability Management, 25(8), 809-823.

Sun, K.A. and Kim, D.Y. (2013). Does customer satisfaction increase firm performance? An application of the American Customer Satisfaction Index (ACSI). International Journal of Hospitality Management, 35 (1),68-77.

Tabachnick, B. and Fidell, L. (2007), Using Multivariate Statistics. 5th ed. USA: Pearson Education.

Tarí, J.; Molina, J.F. and Castejón. J. L. (2007). The relationship between quality management practices and their effects on quality outcomes. European Journal of Operational Research, 183(2), 483-501.

Thurstone, L.L. (1947). Multiple Factor Analysis. Chicago: University of Chicago Press. 16(16), 97-120.

Valmohammadi, C. and Roshanzamir, S. (2015). The guidelines of improvement: Relations among organizational culture, TQM and performance. International Journal of Production Economics, 164 (1), 167-178.

Yeung, A.D.L.; Cheng, T.C.E.; Lai, K.H., (2005). An empirical model for managing quality in the electronics industry. Production and Operations Management, 14(2), 189-204.

Yu, W.; Jacobs, M.A.; Salisbury, W.D., and Enns, H. (2013). The effects of supply chain integration on customer satisfaction and financial performance: An organizational learning perspective. International Journal of Production Economics, 146(1), 346-358.

Zelnik, M.; Maletič, M., Maletič, D. and Gomišček, B., 2012.Quality management systems as a link between management and employees. Total Quality Management \& Business Excellence, 23(1), 45-62.

$\mathrm{Zu}, \mathrm{X}$. (2009). Infrastructure and core quality management practices: how do they affect quality? The International Journal of Quality \& Reliability Management, 26(2), 129-149.

$\mathrm{Zu}, \mathrm{X}$.; Douglas, T. J., and Fredendall, L. D. (2008). The evolving theory of quality management: The role of Six Sigma, Journal of Operations Management, 26 (5), 630-650. 